AC 2009-1452: TEACHING LEADERSHIP PRINCIPLES TO UNDERGRADUATE ENGINEERING AND TECHNOLOGY STUDENTS

Val Hawks, Brigham Young University

Ronald Terry, Brigham Young University 


\section{Teaching Leadership Principles to Undergraduate Engineering and Technology Students}

\section{Introduction}

In an address given in 1997 the former president of Brigham Young University's Board of Trustees, Gordon B. Hinckley, said to students, "I hope you will distinguish yourselves as leaders. I hope your training at this university will endow you with an interesting and powerful sense of responsibility toward the world of which you will be a part." In our technology bound world, we, in engineering and technology, have a unique opportunity to provide leadership as never before. We believe that we must think of our professional mission in light of this challenge to lead.

In commenting on this unique opportunity, Thomas Friedman in The World is Flat quoted Shirley Ann Jackson, then President of Rensselaer Polytechnic Institute and, in 2004, the president of the American Association for the Advancement of Science: " The U.S. is still the leading engine for innovation in the world. But there is a quiet crisis . . The U.S. today is in a truly global environment, and those competitor countries are not only wide awake, they are running a marathon while we are running sprints. If left unchecked, this could challenge our preeminence and capacity to innovate.",2 The authors of the report, The Engineer of 2020 recognized this and further stated, "The economy in which we will work will be strongly influenced by the global marketplace for engineering services. . . . The steady integration of technology in our infrastructure and lives calls for more involvement by engineers in the setting of public policy and in participation in the civic arena. .... attributes needed for the graduates of 2020 . . include such traits as strong analytical skills, creativity, ingenuity, professionalism, and leadership." 3 In the National Academy of Engineering follow-up report entitled Educating the Engineer of 2020, engineering educators were encouraged to provide more training in professional ethics, leadership, knowledge of global technology issues, and understanding of the world's cultures in order to facilitate working in a global arena and engagement in civic activities. $^{4}$

Partly in response to this "quiet crisis," but also to realize the greater potential of our students, the Brigham Young University Ira A. Fulton College of Engineering and Technology administration proposed a strategy to pursue a set of initiatives that would help prepare and develop students as leaders. This strategy described in a paper delivered at an earlier ASEE meeting involves "five key areas of focus: 1) Technical Excellence with a systems emphasis, 2) Leadership, 3) Character Development (including ethics), 4) Global Awareness and 5) Innovation that address the attributes needed for success in a changing global environment."

Subsequently, a course was proposed by college faculty to help our students develop these key attributes. Specifically, the purpose of the proposed class was to address the need to help build leaders who understand and are prepared to address the emerging global world environment from an integrated moral, technical, and social perspective. The course, meets university general education requirements in both the Social Science and Global and Cultural Awareness areas, is 
taught by faculty in the college of Engineering and Technology, and is open to all students in the university.

A major part of the course is designed to emphasize leadership and the development of leadership attributes and skills. This paper presents an assessment of how the class is helping our students' develop in the area of leadership. As part of the assessment, college administrators conducted a focus group of consisting of several members of the class. Of particular interest to the coauthors and college administrators were the following:

- Do the students see themselves as leaders?

- How did the course learning activities help inform the students about their leadership potential?

- Have students thought much about leadership theories and principles and what leadership principles are important to the students?

\section{Description of the leadership part of the course}

The most important principle of learning leadership in this class is based on the notions of absolute integrity and sound moral values. Because the real learning of leadership principles happens experiential, every effort is made to provide such experiences in the setting of the course. Some of these experiential contexts include in-class group and team tasks, case studies, and out-of-class team projects. Some of the team tasks and work require students to project themselves into the emerging global society and condition and discuss hard questions within and as teams such as world population challenges, addressing graft and corruption in the technology industry, global warming, terrorism, and water and energy use.

Because self-awareness is vital in leadership development, to begin the leadership portion of the course, students are instructed in team development and dynamics by introducing them to the Kolb Learning Style model, the Myers-Briggs Type Index, and the Tuckman model of team development. $^{6-8}$ Students take inventories to learn about their own learning styles and personality types to enable them to understand and celebrate the diversity that exists in team and leadership settings. The first major assignment is a team project in which the students are asked to investigate the corruption that exists in technology industries within a country of their choosing. After completing this project, the students are then asked to provide an analysis of the leadership and team interaction that they observed during the project. The last major project of the course is also worked in teams and involves investigating a major societal issue, developing a short survey to ascertain understanding of the issue by the general public, and an executive summary written to the CEO of a major (fictitious) media outlet.

The students are introduced to several leadership theories, including trait and character theories and contingency theories. The students are also introduced to several leadership models. One of these models was developed by college faculty to provide a common language from which to talk about and teach leadership principles. The three basic dimensions of this model include personal development, organizations and teams, and global and cultural awareness. A more detailed description of this model as well as the college strategy is given in another paper in this conference. ${ }^{9}$ Another leadership model taught is one developed by Dallas Merrell, a former 
consultant to the federal government and author of several articles and books in the field of leadership. His model of leadership is defined in his book Leading. ${ }^{10}$

Students are then exposed to various scenarios and cases in which they will need to consider effective leadership practices and principles including the use of types of power, situational leadership concepts of delegation and direction, and the difference between leadership and management.

Students are also given the opportunity to use a 360 self-evaluation instrument developed by Merrell to help them identify their strengths and weaknesses as leaders and as seen by others. They are then expected to formulate one area in which they can improve, work on that area during the semester, and write their observations in a paper submitted at the end of the course.

To serve as a 'capstone' type of project for the leadership section of the course, the students are asked to develop a personal leadership theory and defend it in a short paper.

\section{Question 1: Do the students see themselves as leaders?}

Although, no formal assessment was made of the students during the class regarding this question, it was obvious during the course of instruction that there was a mix of answers to this question. Several students during the class discussions commented that they never thought of themselves as leaders even though they have served in school, club, church, and other leadership capacities and offices.

The focus group sponsored by the college administration helped answer this question. During the Fall 2008 semester, a few (9 men and 1 woman) of the students in one of the sections of the class, participated in this focus group. The students, 5 sophomores, 1 junior, and 4 seniors, were from various majors in the college including electrical engineering, mechanical engineering, manufacturing engineering technology, civil engineering, and information technology. A member of the dean's office formulated some questions and the focus group met to answer the questions. The student responses were recorded and summarized. A few of the questions and response summaries are given below as they relate to Question 1.

\section{Before this class, did you see yourself as a leader?}

- General consensus is that they did not think of themselves as leaders even though they recognized they were continually put in leadership positions. Helped them realize they have been leaders in the past.

- "I had this attitude where I figured I would go to school, graduate, maybe work a little bit and then be a mom and I never associated any of that with leadership - and I was OK with that. Now I think, no, I could apply leadership in the home or wherever I am. That's what I've really got from the class, is that just because I'm not a manager, I'm not aspiring for some higher-up position, I can be a leader, and I am a leader now. I can be a leader wherever I am, no matter what I chose to do. So now, coming out of this class, I do consider myself a leader of sorts."

How has that view changed? Do you think that you're going to be a leader? 
- Unanimous 'yes'. Now that they've studied the qualities of a leader they see themselves as leaders in the future.

\section{How can we help students in this college realize that they do not have to have a formal} calling as a leader in order to be one?

- Require class for graduation. Awareness. Teach development of core values (that the class has helped define).

\section{What does it mean to be a leader, in your minds?}

- Influence, pick core values they will not vacillate on, inspiring change in others, followers follow willingly, effectively communicates the vision to his/her followers, help others find success to excel beyond leader's own ability, must be able to teach others to lead

- " ...what makes a good leaders is less what they do, more what they are."

\section{Why were you interested in taking a class on leadership?}

- "I think what this class does is it kind of teaches me that there is an interpersonal side to [my major] ...If I can't talk to people, if I can only talk to a computer, then I'm not really going to amount to a whole lot in the field, because nobody will want to hire someone who is just dull, mean and can only interact with the machine in front of them."

- Always put in leadership positions, but did not consider self a leader. Figured it would be good to take a class on it, find out what really makes a good leader. (said three times)

\section{Have your ideas about leadership changed after taking the class?}

- "I know mine have. Typically, before this class I always viewed a leader as some kind of management role where a person, through skills, is able to manipulate people into getting a desired outcome. I've since gained a new view on it, that it's more than that. A lot of it is about the personal character of a leader and those kinds of things."

- "Class has given me a vocabulary to express the things I've thought about leadership"

\section{Any closing comments?}

- "It's not like we work until we're finally a leader and then begin affecting people. I think you become a leader as you help others. I think it's a lifelong process... I'm not going to wake up one day, be a leader, and suddenly start affecting people for good. If I start practicing this today, I'll start being a better leader. I think we're leaders now, already."

- "I think the college is already, by nature of the different academic requirements, well geared towards producing student who have the technical capabilities, but again, faith, character and leadership don't really fit into the classic engineering and technology education model. So I think the college has a long way to go if it wants to 
actually accomplish any of those objectives, and I think the college definitely needs to do more."

\section{Question 2: How did the course learning activities help inform the students about their leadership potential?}

The 360-instrument was particularly useful in attempting to assess this question. Students were given the instrument 3-4 weeks before it was due. They were asked to take the self-assessment part of the instrument and then to give it to at least 3 people that knew them, preferably in a leadership and/or employment situation. As part of the assignment, students in one section of the course (69 students) were asked to respond to the following three questions:

1. Before this semester, did you know and understand what a 360-instrument was?

2. Was this instrument helpful to you?

3. What did you learn about yourself that can help you become a better leader?

In response to Question 1, 67 of the students said no and 2 students said yes. One of the students who said yes, had worked in industry for several years before coming back to school and the other had worked a summer job in which a similar instrument was given to employees during his work.

In answering Question 2, 47 students found the instrument helpful, 12 said no, and 10 indicated that it was somewhat helpful. Typical responses for those that said no include the following:

"I would say that this instrument was not overly helpful for me at this time in my life. Although if I were in a position of authority in a business, or organization, then it would be a very useful tool. I just found that a number of the questions didn't really apply to me."

"I think this might be useful down the road a ways when I have had the opportunity to serve in more work oriented leadership positions."

The following are representative responses from students who answered yes to Question 2:

"It gives honest feedback from your fellow associates on where they think you need to improve. It shows your strengths and weaknesses."

"Yes, this instrument was quite helpful to me. It enabled me to get a clearer view of areas of leadership that I need to improve upon. It also showed me that I critique myself more harshly than the people who assessed me."

"I found the 360-instrument to be very helpful. It made me see what qualities I'm really struggling with obtaining and also allowed me to focus on my strengths. I hadn't realized before just how many attributes there are in good leadership. There is a lot to work on and acquire."

Student responses to Question 3 were interesting. Most found something that they could take away that would help them build their leadership potential - even those that had indicated the 
assignment was not helpful. For example, the student who gave the first response listed above for those that had said no to Question 2, said the following regarding Question 3:

"I learned that I really have a hard time delegating and getting help from others. It is a weakness that I need to work on to be successful in any organization."

Comments to Question 3 from students who responded yes to Question 2 include:

"I learned that I scored high on vision and strategy, both according to my peers and myself, and did the most poorly on the alliance section. As a leader, this means that I am motivated to get things done, but I know that I am more comfortable doing them myself, and delegation is difficult for me."

"I learned that I need to set more goals! It quickly became readily apparent that without a definite vision, I can't become an effective leader."

Most students found the 360-instrument to be very useful in identifying areas that they need to work on to develop their leadership potential.

\section{Question 3: Have students thought much about leadership theories and principles and what leadership principles are important to the students?}

The 'capstone' assignment of the students formulating their own personal leadership theory was useful in assessing this question. Following the submission of the personal leadership theory assignment, students were asked to complete a short survey. Fifty-six students returned the survey. On a scale from $1-5$ with 1 being 'Do not agree' and 5 being 'Strongly agree', students were asked to respond to the following comments:

1. Before this assignment, I have not given much thought to my own personal leadership theory.

2. Developing a personal leadership theory is a good idea.

3. I intend to use this as a basis for my leadership activities in the future.

4. I will continue to develop my personal leadership theory throughout my life.

Table 1 contains the results of the students' responses.

Table 1. Results from Survey Regarding the Personal Leadership Theory.

\begin{tabular}{|l|c|}
\hline \multicolumn{1}{|c|}{ Comment } & Average of Student Responses ${ }^{1}$ \\
\hline $\begin{array}{l}\text { Before this assignment, I have not given much } \\
\text { thought to my own personal leadership theory }\end{array}$ & 3.04 \\
\hline $\begin{array}{l}\text { Developing a personal leadership theory is a } \\
\text { good idea }\end{array}$ & 4.63 \\
\hline $\begin{array}{l}\text { I intend to use this as a basis for my } \\
\text { leadership activities in the future }\end{array}$ & 4.36 \\
\hline $\begin{array}{l}\text { I will continue to develop my personal } \\
\text { leadership theory throughout my life }\end{array}$ & 4.50 \\
\hline
\end{tabular}

${ }^{1}$ Scale: 1 (Do Not Agree) - 5 (Strongly Agree) 
The data indicate that the students were very positive about the assignment. The average response to Comment 1 suggests that students are split almost evenly as to whether they had thought much about a personal leadership theory before the assignment. Most of these students had experienced leadership positions in a student group either in high school or at the university or within their church youth organizations. Cleary some had thought more about leadership issues than their peers in similar situations.

Several representative student personal leadership theories are presented below. These statements indicate thoughtful responses to this assignment and, if in deed they form the basis for their future leadership opportunities, indicate these students have developed a good foundation.

I aim to lead by empowering others through focused vision and core values of respect, integrity, innovation, decision, and discipline.

Individuals must possess a Christ-like character of humility, integrity, and service in both their personal and public lives.

A leader provides service; creates structure through organization; teaches, listens, and learns; develops goals; and allows personal freedom.

This assignment can be not only one of the most helpful, but also one of the most thoughtful the students will complete. Though basic leadership principles can be described and, at least in some limited degree agreed on, the application of those principles varies greatly based on situation and personal style. In addition, each person has unique gifts and weaknesses and, after learning of some basic principle and theories, the development of a personal leadership theory allows each student the opportunity to see how they can develop and apply principles about which they feel strongly. An important side benefit to this task is that, as students take this seriously, they see how they can most effectively serve as leaders. This reinforces a basic premise of this course, which is that, though some seem to be blessed from birth with leadership abilities, leadership and leadership attributes can be learned.

\section{Summary and Conclusions}

In response to our college dean's initiative to enhance students' understanding of leadership principles, a new course has been developed. The new course is titled, "Moral Leadership in a Technological World." The course satisfies general education credit in the areas of Social Science and Global and Cultural Awareness, is taught by college of Engineering and Technology faculty, and is open to all university students. In addition, the course satisfies specific discipline accreditation requirements in the area of ethics.

Students that have taken the course have found that the material taught and class projects have been valuable in increasing their awareness in what it means to be a leader and how to lead. Typically, in their last leadership assignment in the course, the development of a personal leadership theory, they express a willingness to commit to be a leader in the future in both their personal and professional lives. 
Our world is richly blessed by technological and engineering advancements, but it is also greatly challenged by the misuse of the same. As technical professionals in our respective disciplines, we have a responsibility to be more than just "commodity" engineers and technologists. We are to provide leadership in solving vexing social, moral and spiritual challenges in this highly connected and complex world. The challenge of leadership has been given and our task is to take it to heart. It is to learn what leadership means and do it.

\section{References}

1. Hinckley, G.B., The BYU Experience, devotional address given at Brigham Young University, Provo, Utah, November 4, 1997.

2. Friedman, Thomas. L., The World is Flat, Picadar, New York, New York, 2007.

3. The Engineer of 2020, Visions of Engineering in the New Century, National Academy of Engineering, 2004.

4. Educating the Engineer of 2020, National Academy of Engineering, 2005.

5. Harb, J., Rowley, R., Magleby, S., and Parkinson, A., "Going Global: Implementation of a College-Wide Initiative to Prepare Engineering and Technology Students for the $21^{\text {st }}$ Century," Proceedings Annual ASEE Meeting, Honolulu, Hawaii, June, 2007.

6. Kolb, D. A., Experiential Learning: Experience as the Source of Learning and Development, Prentice-Hall, Englewood Cliffs, N.J., 1984.

7. Myers, I.B. with Myers, P. B., Gifts Differing: Understanding Personality Type, DaviesBlack Publishing, Mountain View, CA, 1980.

8. Tuckman, B.W., "Developmental Sequence in Small Groups," Psychological Bulletin, 63, 384-399, 1965. The article was reprinted in Group Facilitation: A Research and Applications Journal, No. 3, Spring 2001 and is available as a Word document at http://dennislearningcenter.osu.edu/references/GROUP\%20DEV\%20ARTICLE.doc.

9. Hawks, V., Harb, J., Magleby, S., and Parkinson, A., "A College-wide Approach for Teaching and Developing Leadership: Model, Framework and Outcomes," submitted for consideration in the Proceedings Annual ASEE Meeting, Austin, Texas, June, 2009.

10. Merrell, D., Leading, Knowledge Gain Publications, 2000. 